\title{
WIȘĀYAH DAN AMANAH: ANALISIS PERBANDINGAN UNDANG-UNDANG SYARIAH DAN SIVIL DALAM PERANCANGAN HARTA PUSAKA
}

\section{Wișāyah and Trust: A Comparison Study Between Shariah and Civil Law in Islamic Inheritance Planning}

\author{
Muhamad Mu'izz Abdullah' \\ Abdul Bari Awang ${ }^{2}$ \\ Nasrul Hisyam Nor Muhammad ${ }^{3}$
}

\begin{abstract}
The appointment of executors through wișayah and trust in Islamic estate planning can guarantee the benefit of the beneficiary and the trust property itself. This concept of trust has been evolved from the time of the Prophet SAW. However, the concept of trust practising in the industry nowadays is to be quite different compare to Islamic concept. Therefore, this article will study the concept of wișayah and trust in the care of underage
\end{abstract}

1 Ph.D Candidate, Department of Fiqh and Usul Fiqh, Islamic International University of Malaysia, Kuala Lumpur; Executive of Amanah Raya Berhad, Kuala Lumpur, muizzziela8990@gmail.com.

2 Associate Professor, Department of Fiqh and Usul Fiqh, Islamic International University of Malaysia, Kuala Lumpur, abdbari@iium.edu.my

3 Associate Professor, Islamic Civilization Academy, Faculty of Social Sciences and Humanities, Universiti Teknologi Malaysia, Skudai, nasrul@utm.my 
beneficiaries from two different perspectives; Civil law and Shariah law. The author uses qualitative research by applying library approaches and interviews. Amanah Raya Berhad was chosen as a sample of study to indicate the civil trust concept. The findings of this study will be analyzed based on the descriptive and comparative analysis. The result shows that wișayah and trust are two instruments of Islamic estate planning that have the same objective even though they are referring to different laws. In conclusion, the appointment of an executor through the concept of wișayah and trust is important to protect the rights and the property of the minor after the deceased of the donor.

Keywords: wișāyah, civil trust, Islamic trust, beneficiary, Islamic estate planning

\section{PENDAHULUAN}

Perancangan harta pusaka semasa hidup adalah penting dan mempunyai kesan yang signifikan, terutamanya sekiranya si mati meninggalkan anak di bawah umur. Othman Yaacob menjelaskan bahawa konsep perancangan harta pusaka yang diiktiraf Islam adalah meliputi cara pengumpulan harta, mengurus, mentadbir, adil dalam pembahagian aset dan urusan pindah milik kepada wariswaris mengikut Hukum Syarak. ${ }^{4}$ Kewujudan pelbagai produk dan instrumen peramanahan dalam industri perancangan harta pusaka di Malaysia kini, memberi peluang dan ruang kepada pemilik harta untuk melantik pemegang amanah (wași $)$ bagi melaksanakan hajatnya. Pelaksanaannya perlu difahami dengan sebaiknya kerana Syarak mengambil berat perancangan harta pusaka yang sistematik sebagai memenuhi tuntutan maqāṣìd hiffz al-māl. Kegagalan memahaminya dan melaksanakan pengamanahan tanpa panduan yang jelas akan memberi mudharat kepada warisnya dalam kalangan kanak-kanak bawah umur.

Dalam pengurusan harta amanah di Malaysia, terdapat dua undang-undang yang menjadi rujukan dalam perlembagaan negara, iaitu undang-undang sivil dan undang-undang Syariah. Keunikan Malaysia juga adalah jelas apabila undang-undang adat seperti adat perpatih di Negeri Sembilan turut dijadikan panduan dalam pengurusan harta amanah. Ini disebabkan kuatnya pengaruh

4 Othman Yaacob, 'Pembentukan Trust Hibah sebagai Alternatif Perancangan Harta,' dalam Harta Amanah Orang Islam di Malaysia: Perspektif UndangUndang dan Pentadbiran, ed. Siti Mashitoh Mahamood (Kuala Lumpur: Penerbit Universiti Malaya, 2006), 171-207. 
adat melayu semenjak kedatangan Islam ke Tanah Melayu. ${ }^{5}$ Namun dalam artikel ini, kajian akan memfokuskan kepada dua instrumen pengamanahan yang dipraktikkan di Malaysia iaitu wișāyah dan amanah. Wișāyah adalah salah satu instrumen amanah dalam Islam yang mempunyai sandaran hukum tersendiri. Manakala amanah adalah instrumen perancangan harta pusaka yang tertakluk di bawah statut undang-undang sivil. ${ }^{6}$

Kedua-dua instrumen pengamanahan ini dipraktikkan oleh masyarakat Muslim di Malaysia dalam melindungi hak-hak dan kepentingan benefisiari bawah umur. Kedua-duanya mempunyai kesan yang signifikan dalam menunaikan hasrat pewasiat dan ianya dijamin dalam perlembagaan Malaysia. Justeru, konsep pelaksanaan kedua-dua instrumen pengamanahan ini perlu dianalisis untuk melihat sejauh manakah persamaan dan perbezaan di antara keduanya dalam pengurusan harta pusaka. Konsep amanah sivil yang kini dipraktikkan secara meluas di syarikat peramanahan di Malaysia akan ditinjau dengan lebih teliti untuk melihat sejauh manakah pelaksanaannya memenuhi tuntutan Syariah.

\section{KONSEP AMANAH DAN PELAKSANAANNYA DALAM ISLAM}

\section{Konsep Amanah Islam}

Perkataan amanah adalah berasal daripada kata terbitan al-amnu yang bererti keamanan, dan ketenangan. Manakala al-Amin adalah merujuk kepada individu yang dipercayai untuk melaksanakan sesuatu perkara dipertanggung jawabkan. Di dalam al-Quran Allah SWT menggunakan perkataan al-Amin untuk menggambarkan sifat amanah Baginda SAW dalam menyampaikan risalah Tuhan-Nya dan tidak khianat mengubah isi kandungan wahyu. ${ }^{7}$ Di antaranya adalah surah al-Dukhān ayat 18 dan surah al-A'rāf ayat 68 :

5 Izawati Wook et al., 'Tanah Adat di Negeri Sembilan: Undang-Undang, Pelaksanaan dan Realiti,' Malaysian Journal of Syariah and Law, vol. 5 (Khas) (2017): 1-10; Norazlina Abdul Aziz, Irini Ibrahim \& Mohd Norhusairi Mat Hussin, 'Harta Sepencarian/Aset Perkahwinan Bagi Pembubaran Perkahwinan di Bawah Seksyen 51 Akta Membaharui Undang-undang (Perkahwinan dan Perceraian) 1976 Serta Akta Undang-Undang Keluarga Islam (Wilayah-Wilayah Persekutuan) 1984,' Journal of Shariah Law Research, vol. 4/1 (2019), 2.

6 Nasrul Hisyam Nor Muhamad, Wasiat dan Wisayah dalam Perancangan Harta: Prinsip dan Amalan (Skudai: UTM Press, 2012), 155-157.

7 Muhamad Sa'īd Ṭanțāwī, al-Tafsīr al-Wasìt li al-Qur'ān al- 'Ażīm, vol. 5 (Qāhirah: Dār al-Naḥ̣̣ah, 1997), 301. 


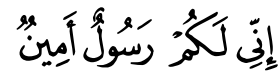

"Sesungguhnya aku adalah utusan Allah SWT yang dipercayai."

(Surah al-Dukhān, 44: 18)

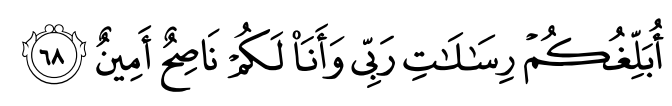

"Aku menyampaikan nasihat Tuhanku, sesungguhnya aku adalah seorang pemberi nasihat yang dipercayai."

(Surah al-A'rāf, 7: 68)

Manakala konsep amanah Islam ini sekiranya ditinjau dari perspektif perancangan harta pusaka, ianya berkait rapat dengan tugasan dan ciri-ciri yang perlu dimiliki oleh seorang penjaga (wașì). Perbincangan konsep amanah Islam merupakan sesuatu yang al-durürī kerana ianya melibatkan kepercayaan seorang pewasiat ( $m \bar{u} s \bar{\imath})$ dalam mengamanahkan sesuatu perkara kepada orang dipercayainya. ${ }^{8}$ Seseorang yang mengkhianati sesuatu amanah yang diberikan bukan sahaja berdosa, malah akan menyebabkan mudarat kepada harta amanah dan benefisiari.

Allah SWT berfirman di dalam al-Quran:

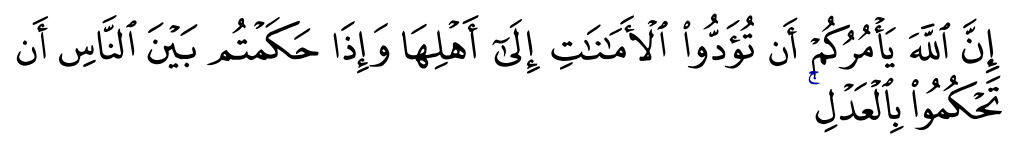

"Sesungguhnya Allah menyuruh kamu supaya menyerahkan segala jenis amanah kepada ahlinya (yang berhak menerimanya), dan apabila kamu menjalankan hukum di antara manusia, (Allah menyuruh) kamu menghukum dengan adil."

(Surah al-Nisā', 4: 58)

\footnotetext{
Andi Mohamad Zulkhairi Muhamad, 'Konsep Amanah dalam Pengurusan Islam dari Sudut Maqasid Syariah (Penjagaan Harta),' Prosiding Seminar Pengurusan Islam: Ke Arah Pemantapan Ummah (Bangi: Jabatan Pengajian Dakwah dan Kepimpinan, Fakulti Pengajian Islam, Universiti Kebangsaan Malaysia, 2015), $1-9$.
} 
Ulama fiqh mengklasifikasikan amanah dalam pelbagai akad seperti berikut: ${ }^{9}$

a) Akad wakālah: "Pihak yang diwakilkan akan melaksanakan tugasan yang diamanahkan mewakili orang yang diwakili".

b) Akad kafālah: "jaminan (ḍamān) yang dilakukan oleh penjamin (kafìl) ke atas pihak ketiga (makfül 'anhu) di atas kewajipan yang perlu dilaksanakan kepada pihak kedua"

c) Akad wișāyah: "pelantikan seorang penjaga (wașī) untuk menguruskan harta dan anaknya selepas kematiannya".

d) Akad haḍ̄anah: "penjagaan seorang kanak-kanak bawah umur yang belum mencapai akhir baligh yang tidak mampu menguruskan diri sendiri sama ada ketika berkahwin atau telah bercerai."

e) Akad wilāyah: "pemberian kuasa (wilāyah) kepada seorang wali (wakīl) sewaktu masih hidup untuksesuatu urusan".

f) Akad wad̄'ah: "penyerahan suatu hak milik kepada seseorang (mudī') untuk tujuan penyimpanan".

g) Akad wașiat: "Pemberian sesuatu selepas kematian".

h) Akad $i$ 'ārah: "pemilikan manfaat tanpa balasan pada masa hidup".

Kesemua akad ini memberi maksud yang satu iaitu memberi kepercayaan kepada seorang wașī di atas pemilikan sesuatu harta. Pembentukan amanah dalam perundangan Islam kebanyakannya terbentuk melalui akad-akad di atas. Selain pembentukan amanah menerusi akad, amanah juga boleh diwujudkan menerusi peruntukan undang-undang contohnya peranan baitulmal sebagai pemegang harta orang Islam seperti zakat. Selain itu, amanah juga boleh wujud dengan perintah mahkamah seperti pelantikan pentadbir bagi orang yang tidak mempunyai kapasiti menguruskan harta. Namun perbincangan dalam artikel ini hanya memfokuskan pada konsep pelaksanaan wișāyah sahaja sebagai salah satu elemen dalam amanah Islam.

9 'Abd Allāh Muhammad Sa‘īd, 'al-Wișāyah fī al-Fiqh al-Islāmī wa Qānūn alAḥwāl al-Shakhṣiyyah al-Urdūn̄̄: Dirāsah Muqāranah' (Risālah al-Duktūrah, fī al-Fiqh wa Ușūl al-Fiqh, Kulliyyah al-Dirāsāh al-'Ulyā, al-Jāmi'ah al-Urdūniyah, 2005), 22-26; Ashrāf Ḥaṇal al-Shā'īr, 'Aḥkām al-Wișāyah fī al-Sharī'ah alIslāmiyah wa Madā Tațbīqatuhā fĩ al-Maḥākim al-Shar'iyyah fī Qiṭa' al-Ghazzah' (Risālah al-Mājistir, Kulliyyah al-Shārīah wa al-Qānūn, al-Jāmi‘ah al-Islāmiyyah bi Ghazzah, 2006), 9-13. 


\section{Pelaksanaan Wișāyah di Malaysia}

Wișāyah adalah sebahagian daripada elemen dalam amanah. Konsep asalnya adalah melibatkan pelantikan seorang wași yang dipercayai sewaktu hidup pewasiat bagi penjagaan anaknya di bawah umur, pelaksanaan wasiat, melunaskan hutang-piutang, pemulangan barang amanah dan lain-lain. ${ }^{10}$ Takrifan ini turut menyamai dengan undang-undang keluarga Islam di Yaman (No. 36) dan Iraq (No. 75) yang menjelaskan:

"Wași adalah individu yang dilantik menguruskan urusan kanakkanak di bawah umur selepas kematian muși yang merangkumi urusan hutang, penjagaan anak bawah umur dan harta mereka. "11

Berdasarkan definisi ini, pelaksanaan wișāyah ini lebih tertumpu kepada urusan penjagaan kanak-kanak di bawah umur selepas kematian mușī. Maksud yang sama juga dikemukakan oleh Qanun Aḥkām al-Wilāyah 'Alā al-Māl (No. 119/1952):

"Sebagai wasiat dengan melantik wașī yang bertanggung jawab ke atas hal ehwal anak-anak di bawah umur selepas kematian pewasiat (pemberi amanah)." 12

Walau bagaimanapun, definisi yang diberikan oleh Qanun Ahkām alWilāyah 'Alā al-Māl ini seolah-olah menerangkan bahawa wiṣāyah adalah satu wasiat.

Persamaan ini timbul kerana perkataan wișāyah dan wasiat adalah dari kata terbitan yang sama iaitu al-iṣa'. Di samping itu, rukun-rukun di antara keduaduanya terbina melibatkan muṣī (pewasiat), wașī (pihak diamanahkan), musa fih, dan sighah (lafaz pengamanahan). Oleh kerana itu, terdapat dikalangan sarjana yang menggunakan wiṣāyah merujuk kepada wasiat iaitu suatu dokumen

10 Muștafā al-Khin, Muștafā al-Bughā, 'Al̄̄ al-Sharbaj̄̄, al-Fiqh al-Manhajī 'alā Madhhab al-Imām al-Shāfi ‘̄, vol. 5 \& 6 (Dimashq: Dār al-Qalam, 1992), 59.

11 'Abd Allāh Muhammad Sa'īe, 'al-Wișāyah fī al-Fiqh al-Islāmī wa Qānūn alAḥwāl al-Shakhșiyyah al-Urdūnī: Dirāsah Muqāranah,' 19.

12 Nasrul Hisyam Nor Muhamad, Wasiat dan Wisayah dalam Perancangan Harta: Prinsip dan Amalan, 97. 
wișāyah atau pengamanahan harta. ${ }^{13}$ Namun begitu, Badruddin Hj Ibrahim menjelaskan bahawa wișāyah adalah lebih tertumpu kepada pengurusan harta dan perlindungan kepada kanak-kanak bawah umur termasuk anak yatim dan orang kurang upaya selepas kewafatan penjaga. ${ }^{14}$

Konsep wișāyah walaupun ianya dilihat menyerupai wasiat dalam Islam, akan tetapi konsep wasiat adalah lebih meluas. Dari segi definisi, wasiat bererti satu pemberian (tabarru') seseorang pewasiat semasa hayatnya kepada pihak yang lain. Harta yang diwasiatkan sama ada dalam bentuk harta, hutang atau manfaat manakala pelaksanaannya pula berlaku adalah selepas kematian pewasiat. ${ }^{15}$ Melalui definisi wasiat ini, adalah jelas terdapat perbezaan di antara wasiat dan wiṣāyah. Secara amnya, akad wasiat adalah mengenai persoalan siapa yang menjadi benefisiari harta wasiat yang melibatkan bukan ahli waris atau yang tidak mendapat habuan faraid. ${ }^{16}$ Manakala wișāyah topik perbincangannya adalah mengenai pelantikan wāsì yang layak untuk menguruskan subjek wișāyah tersebut. Perbezaan ini jelas menerusi definisi yang diberikan oleh para fuqāh $\bar{a}$ ' bahawa konsep wiṣāyah adalah suatu penyerahan hak berdasarkan kewaliannya, perlantikan sama ada menerusi mușī atau hakim, pelaksanaannya untuk melindungi nyawa dan harta, diizinkan

13 Al Azifah Mohd Safie, 'Penderafan Dokumen Wasiat Islam di Amanah Raya Berhad: Analisis Menurut Perspektif Islam,' (Disertasi Sarjana, Jabatan Syariah dan Undang-Undang, Akademi Pengajian Islam, Universiti Malaya, 2010), 7578; Kasimah Kamaruddin \& Md. Yazid Ahmad, 'Analysis of the Understanding of Muslim Will Writing in Melacca,' Islāmiyyāt, vol. 34 (2012): 71-82; Naziree Md Yusof, 'Hukum Wisoyah \& Realiti Permasalahannya dalam Konteks Perancangan Pusaka Islam,' Jurnal Muamalat, vol. 1 (2008): 73-102; Suhaili Alma'amun, 'Islamic Estate Planning : Analysing the Malaysian Perceptions on Wasiyyah (Will) and Bequest Practices,' (Ph.D Thesis, Institute of Middle Eastern and Islamic Studies, School of Government and International Affair, Durham University 2010), 116.

14 Badruddin Hj Ibrahim, 'The Concept of al-Wisayah with Special Reference to the Administration of A Minor's Property Under Islamic Law and the Enacted Islamic Law in Malaysia,' (Ph.D Thesis, Kulliyyah Undang-Undang Ahmad Ibrahim, Universiti Islam Antarabangsa Malaysia, 2006); 24-38. Lihat juga Badruddin $\mathrm{Hj}$ Ibrahim, 'Will of Entrustment As A Means of Protection of Children's Right To Property in Islamic Law,' Australian Journal of Basic and Applied Sciences, vol. 6/11 (2012): 85-94.

15 Sayyid Sābiq, Fiqh al-Sunnah, vol. 3 (Bayrūt, Lubnān: Dār al-Kutub al-'Arabī, 1997), 583.

16 Nasrul Hisyam Nor Muhamad, Wasiat dan Wisayah dalam Perancangan Harta: Prinsip dan Amalan, 98. 
oleh Syarak untuk mengembangkan harta amanah, dan wiṣāyah mempunyai tempoh peramanahan yang tersendiri seperti mencapai umur akhir baligh. ${ }^{17}$

Konsep wișāyah ini juga bertepatan dengan al-Quran dalam pengurusan harta amanah apabila perkataan anak-anak yatim (al-yatāma) dan orang bodoh (al-sufaha ') disebutkan secara khusus seperti tercatat dalam beberapa surah di dalam al-Quran diantaranya surah surah al-Baqarah (2): 220 dan surah al-Nisā' (4): 5, 6, 10 dan 127. Manakala garis panduan penjagaan harta amanah turut digariskan di dalam surah al-An'ām (6): 152 dan al-Isrā' (17): 134. Secara praktikalnya, pelaksanaan wișāyah ini telahpun berlaku pada zaman Baginda SAW dan diikuti oleh para sahabat. Baginda SAW pernah menasihati seorang sahabat yang sangat miskin dan mempunyai tanggungan anak yatim melalui sabdanya:

$$
\text { كل من مال يتيمك غير مسرف، و لا مبادر، و لا متأثّل }
$$

"Makanlah sebahagian daripada harta anak yatim (bawah tanggungan) kamu tanpa berlebihan, tidak berlaku pembaziran dan tidak mengambil harta pokoknya (modalnya) ". ${ }^{18}$

Ini menjadi bukti bahawa Baginda SAW sangat menitik beratkan konsep wiṣāyah malah Baginda SAW menjamin wași yang amanah balasannya adalah syurga seperti di dalam riwayat al-Bukhārī:

$$
\text { أنا و كافل اليتيم في الجّنّة هكذا. وقال بإصبعيه السّبّابة والوسطى }
$$

"Aku dan penjaga anak yatim adalah seperti ini di dalam syurga.

(Baginda SAW mengisyaratkan jari telunjuk dan jari tengah).” 19

Pelaksanaan wiṣāyah bukan sahaja diharuskan Syarak, malah pelaksanaannya juga turut dijamin dalam Perlembagaan Persekutuan Malaysia khusus berkaitan urusan keagamaan yang diletakkan di bawah Jadual Kesembilan, Senarai 2, Senarai Negeri. Di antara harta amanah yang disenaraikan dalam Perlembagaan Persekutuan ini adalah termasuk berkenaan

17 'Abd Allāh Muḥammad Sa‘īed, 'al-Wișāyah fī al-Fiqh al-Islāmī wa Qānūn alAḥwāl al-Shakhșiyyah al-Urdūnī: Dirāsah Muqāranah,' 20-21.

18 Abī Dāwud, Sulayman bin al-Ash'ath, Sunan Abī Dāwud, vol. 3 (Bayrūt, Lubnān: al-Maktabah al-'Așriyyah, t.t.), 115, "Kitāb al-Wașāyā, Bāb Mā Jā’a fī Mā li Wali al-Yatīm An Yanāla Min Mal al-Yatīm, no. hadis 2872.

19 Al-Bukhārī, Muḥammad bin Ismā‘̄̄l, Șaḥ̄h al-Bukhārī, vol. 8 (Bayrūt, Lubnān: Dār Ṭūq al-Najāh, 2001), 9, "Kitāb al-Ādab, Bāb Faḍl Man Ya'ūlū Yatīmā, no. hadis 6005 . 
harta berwasiat dan tidak berwasiat, pemberian (hibah), wakaf, amanah khairat, zakat dan baitulmal. Melalui peruntukan bidang kuasa yang telah ditetapkan Perlembagaan Persekutuan ini, Badan Perundangan Negeri mempunyai bidang kuasa untuk membuat rang undang-undang tersendiri termasuk dalam perkara yang melibatkan hal ehwal orang Islam pada Bahagian VI "Perhubungan Antara Persekutuan Dengan Negeri-Negeri” di bawah Perkara 73 hingga 76 Perlembagaan Persekutuan.

Oleh kerana itu, Majlis Agama Islam Negeri (MAIN) adalah pemegang amanah tunggal (sole trustees) melibatkan harta wakaf, nazar dan amanah di Malaysia. Ini seperti dinyatakan dalam Bahagian (vi)(89) Enakmen 1 Pentadbiran Agama Islam (Negeri Selangor):

“...Majlis hendaklah menjadi pemegang amanah yang tunggal:

a) semua wakaf, sama ada wakaf am atau wakaf khas

b) semua nazr am; dan

c) segala jenis amanah yang mewujudkan apa-apa amanah khairat bagi menyokong dan memajukan agama Islam atau bagi faedah orang-orang Islam mengikut Hukum Syarak, "

Harta amanah yang dimaksudkan merangkumi aset alih dan juga tidak alih. Walaupun perkataan wișāyah tidak digunakan secara khusus dalam enakmen setiap negeri, tetapi konsep pelaksanaannya dapat diketahui melalui peruntukan undang-undang yang terkandung di dalamnya. Sebagai contoh, konsep wișāyah dibincangkan di dalam Akta 303, Akta Undang-Undang Keluarga Islam (Wilayah Persekutuan) 1984 pada bahagian (vi): "Nafkah Isteri, Anak Dan Lain-Lain" dan bahagian (vii): "Hak Penjagaan". Perlantikan wași yang betul dan sempurna syaratnya seperti dinyatakan dalam seksyen 81 dan seksyen 82 adalah penting untuk memastikan kepentingan diri dan harta benefisiari terjaga. Oleh kerana itu, di dalam seksyen 86 Mahkamah Syariah mempunyai bidang kuasa untuk menentukan hak jagaan al-qașīr dan bertindak sebagai penjaga sekiranya pelantikan wașī tidak dilakukan ketika hidup mușī sebagaimana dinyatakan:

1. “....Mahkamah boleh dengan perintah meletakkan kanakkanak itu dalam jagaan mana-mana orang lain atau mana-mana persatuan yang tujuannya adalah termasuk kebajikan kanakkanak..." 
$3 \ldots$

$4 \ldots$

5. Mahkamah boleh, jika perlu, membuat perintah interim untuk menempatkan kanak-kanak itu dalam jagaan mana-mana orang atau institusi atau persatuan dan perintah itu hendaklah serta merta dikuatkuasakan dan terus dikuatkuasakan sehingga Mahkamah membuat perintah bagi penjagaan itu."

Perlantikan wașī hakim ini bertepatan dengan sabda Baginda SAW:

$$
\text { فالسّلطان وليّ من لا وليّي له }
$$

"Seorang sultan (hakim) adalah wali bagi seseorang (al-qașir) yang tiada wali (penjaga)." 20

Berdasarkan seksyen 86 di atas, dinyatakan bahawa mahkamah boleh melantik mana-mana institusi atau persatuan yang berorentasikan kebajikan sebagai wașī. Ini bermaksud, konsep wișāyah yang pada asalnya adalah melibatkan penjaga individu telah berkembang dan pelantikan wașī sewaktu hidup boleh dipertanggungjawabkan kepada mana-mana institusi atau pusat jagaan kanak-kanak yang berkelayakan. Kenyataan ini turut disokong oleh Naziree Md Yusof yang menyatakan bahawa konsep wișāyah kini telah mengalami evolusi daripada konsep asalnya berbanding konsep pelaksanaannya di zaman Baginda SAW. Mekanisme pelaksanaanya kini telah diperkemas dan didokumentasikan secara bertulis. Disenaraikan di dalamnya hajat seseorang mușī; cara pembayaran nafkah kepada benefisiari, harta sepencarian, KWSP, pembahagian faraid, hutang, zakat, nazar, haji wasiat, hibah dan wakaf. ${ }^{21}$

\section{KONSEP AMANAH DAN PELAKSANAANNYA DALAM UNDANG- UNDANG SIVIL}

\section{Konsep Amanah Sivil}

Perbincangan konsep amanah sivil memberikan pengertian berbeza berbanding konsep amanah Islam. Menurut Nasrul Hisyam tiada definasi khusus untuk menerangkan maksud amanah atau "trust" dalam statut bertulis di Malaysia melainkan definisi tersebut hanya dapat diketahui melalui penghakiman atau

\footnotetext{
20 Abī Dāwud, Sulayman bin al-Ash'ath, Sunan Abī Dāwud, vol. 2, 229, "Kitāb alNikāh, Bāb fì al-Walī, no. hadis 2083.

21 Naziree Md Yusof, 'Hukum Wisoyah \& Realiti Permasalahannya dalam Konteks Perancangan Pusaka Islam,' 82-83.
} 
huraian bagi sesebuah kes. ${ }^{22}$ Namun merujuk kepada penulisan bekas Ketua Hakim Negara Tun Salleh Abbas, perkataan amanah dapat dikenal pasti secara umum dan diketahui bidang kuasanya dengan merujuk kepada Perlembagaan Persekutuan, Jadual Kesembilan, Senarai Perundangan, Senarai 1, Senarai Persekutuan, 4(e)(i):

“(i) Kontrak; perkongsian, agensi dan kontrak khas yang lain; majikan dan pekhidmat; rumah inapan dan tuan rumah inapan; perbuatan salah boleh dakwa; harta dan pindah hakmiliknya serta hipotekasinya, kecuali tanah; bona vacantia; ekuiti dan amanah...."

Bagi melihat definisi amanah dengan lebih jelas, tafsiran bagi kes Yong Nyee Fan \& Sons Sdn. Bhd v Kim Guan \& Co. Sdn. Bhd [1979] 1 MLJ $182^{23}$ dijadikan rujukan. Hakim pada ketika itu, Hashim Yeop Sana J telah memutuskan seperti berikut:

"It has been found difficult to give a satisfactory definition of a trust but it has been accepted that the most satisfactory definition is by Professor Keeton which definition is that a trust is the relationship which arises wherever a person called the trustee is compelled in equity to hold property, real or personal, and whether by legal or equitable title, for the benefit of some persons (whom he may be one) or for some object permitted by law, in such a way that the real benefit of the property accrues, not to the trustee, but to the beneficiaries or other objects of the trust."

Berdasarkan tafsiran mahkamah di atas, konsep amanah sivil memiliki tiga elemen utama: penderma (settlor), benefisiari, harta amanah. Pelaksanaannya termeterai melalui surat ikatan amanah (trust deed) yang terkandung di dalamnya terma dan syarat tertentu yang dipersetujui antara kedua pihak. Dalam pelaksanaan amanah sivil ini, benefisiari boleh terdiri daripada penderma itu sendiri atau pihak ketiga sama ada individu atau institusi. Manakala, harta amanah di atas bermaksud harta alih dan tidak alih yang menjadi perkara (subject matter) amanah itu sama ada wakaf atau tidak. ${ }^{24}$

22 Nasrul Hisyam Nor Muhamad, Wasiat dan Wisayah dalam Perancangan Harta: Prinsip dan Amalan, 104-108.

23 Yong Nyee Fan \& Sons Sdn. Bhd v Kim Guan \& Co. Sdn. Bhd [1979] 1 MLJ 182.

24 Tun Abdul Hamid Omar, 'Bidang Kuasa Mahkamah Sivil dalam Pentadbiran Harta Amanah di Malaysia,' https://tunabdulhamid.me/2001/11/bidangkuasamahkamah-sivil-dalam-pentadbiran-harta-amanah-dimalaysia/, dicapai pada 13 April 2020. 
Amanah sivil mempunyai perbezaan ketara dengan amanah Islam seperti yang dirujuk dalam Jadual Kesembilan, Senarai Perundangan, Senarai II, Senarai Negeri, Perenggan 1. Amanah Islam hanya tertumpu kepada pewarisan berwasiat dan tidak berwasiat, pertunangan, perkahwinan, perceraian, mas kahwin, nafkah, pengangkatan, kesahtarafan, penjagaan, alang, pecah milik dan amanah bukan khairat, Zakat, Fitrah dan Baitulmal. Sebaliknya konsep amanah sivil yang dibincangkan dalam bab ini adalah lebih luas. Antara instrumen harta alih yang terlibat adalah seperti saham amanah (unit trust), tabung amanah (trust fund), pelaburan pemegang amanah (trustee investment), akaun amanah (trust account), dan harta tak alih seperti amanah hartanah (poroperty trust) dan lain-lain lagi. ${ }^{25}$

Konsep pelaksanaan amanah sivil membenarkan seseorang individu untuk membuat sesuatu peramanahan sewaktu hidupnya bagi manfaat dirinya atau manfaat orang lain. Peramanahan yang terbentuk ini adalah berdasarkan undang-undang dan wujud dalam pelbagai bentuk seperti statutori, persendirian dan awam dan ianya boleh terlaksana melalui wasiat, surat ikatan amanah (trust deed) atau secara lisan. ${ }^{26}$

Secara umumnya, Akta Pemegang Amanah 1949 (Akta 208) dan Akta Syarikat Amanah 1949 (Akta 100) dijadikan rujukan utama dalam undangundang amanah sivil di Malaysia. Manakala undang-undang amanah lain yang terpakai adalah seperti berikut:

1. Akta Pemegang Amanah (Perbadanan) 1952

2. Akta Perbadanan Amanah Raya 1955 (Akta 532)

3. Akta Syarikat Amanah Labuan (1990 (Akta 442)

4. Akta Pembahagian 1958 (Akta 300)

5. Akta Pesaka Kecil (Pembahagian) 1955 (Akta 98)

6. Akta Probate Dan Pentadbiran 1959 (Akta 97)

7. Akta Perwarisan (Peruntukan Keluarga) Akta 1971

8. Akta Wasiat 1959 (Akta 346)

9. Akta Insuran 1996

10. Akta Kanun Tanah Negara 1965

25 Abdullah Muhammad, 'Pengamanahan Harta Orang Islam di Malaysia,' dalam Harta Amanah Orang Islam di Malaysia: Perspektif Undang-Undang dan Pentadbiran, ed. Siti Mashitoh Mahamood (Kuala Lumpur: Penerbit Universiti Malaya, 2006), 124.

26 Rosmah Mansor (Pengurus Jabatan Pentadbiran Amanah, Amanah Raya Berhad), dalam temu bual beliau bersama penulis pada 5 Mac 2020 . 
Berdasarkan peruntukan undang-undang sedia ada, pembentukan amanah berlaku dalam pelbagai bentuk: ${ }^{27}$

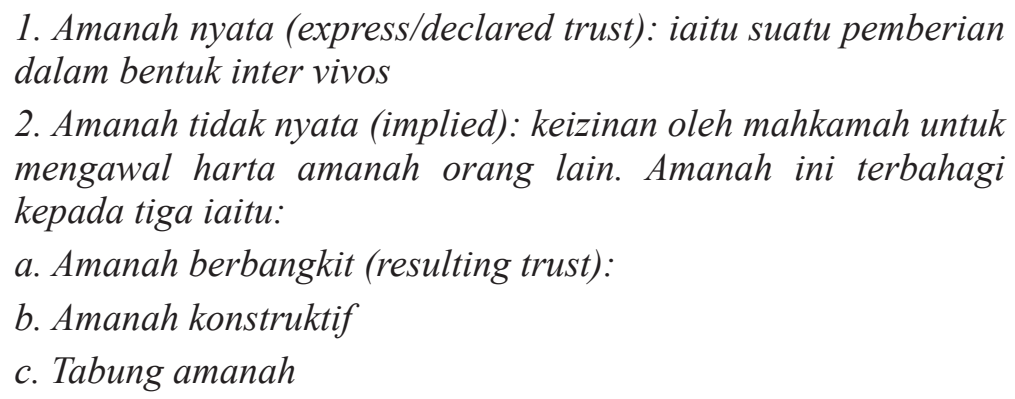

1. Amanah nyata (express/declared trust): iaitu suatu pemberian dalam bentuk inter vivos

2. Amanah tidak nyata (implied): keizinan oleh mahkamah untuk mengawal harta amanah orang lain. Amanah ini terbahagi kepada tiga iaitu:

a. Amanah berbangkit (resulting trust):

b. Amanah konstruktif

c. Tabung amanah

Konsep amanah sivil adalah terpakai kepada orang Islam dan bukan Islam. Manakala konsep amanah Islam hanya terhad kepada orang Islam sahaja. Melihat kepada perbezaan ini, Akmal Hidayah dan Tajul Aris menjelaskan bahawa undang-undang amanah sivil di Malaysia adalah mengatasi undangundang amanah Islam. Ini kerana Malaysia terikat dengan undang-undang Inggeris, terutamanya melibatkan prinsip ekuiti. Sekiranya berlaku pertindihan dalam pelaksanaan amanah, undang-undang sivil akan dijadikan rujukan dan dibicarakan di mahkamah sivil. Ini dapat dilihat di dalam beberapa kes seperti: ${ }^{28}$

1. TM Feroze Khan \& Ors lwn Meera Hussain TM Mohamed Mydin'²9

Dalam kes ini, Mahkamah Rayuan telah memutuskan bahawa sebarang kes melibatkan amanah perlu dirujuk kepada Mahkamah Sivil sama ada melibatkan orang Islam atau bukan Islam.

2. Wan Naimah Lwn Wan Mohamad Nawawi ${ }^{30}$

\footnotetext{
27 Rosmah Mansor (Pengurus Jabatan Pentadbiran Amanah, Amanah Raya Berhad), dalam temu bual beliau bersama penulis pada 5 Mac 2020.

28 Akmal Hidayah Halim, 'The Legality of A Living Trust As An Instrument for Islamic Wealth Management: A Malaysian Perspective,' IIUM Law Journal, vol. 19/1 (2011): 35-50. Lihat juga Akmal Hidayah Halim \& Tajul Aris Ahmad Bustami, 'Pelaksanaan Hibah Amanah sebagai Suatu Instrumen Pengurusan Harta Islam di Malaysia,' Kanun: Jurnal Undang-Undang Malaysia, vol. 29/2 (2017): 90-115.

29 TM Feroze Khan \& Ors lwn Meera Hussain TM Mohamed Mydin [2006] 3 CLJ 616

$30 \quad$ Wan Naimah lwn Wan Mohamad Nawawi (1974) 1 MLJ 41
} 
Begitu juga dalam kes ini, Mahkamah Persekutuan telah memutuskan kes amanah juga terpakai kepada orang Islam.

Berdasarkan beberapa kes mahkamah di atas, timbul persoalan dalam kalangan sarjana adakah Mahkamah Sivil mempunyai bidang kuasa lebih tinggi daripada bidang kuasa Mahkamah Syariah, khususnya melibatkan harta amanah orang Islam. ${ }^{31}$ Persoalan ini telah dirungkai oleh Mohamad Naser bahawa undang-undang perwarisan Islam seolah-olah tiada fungsi kerana belakunya pertindihan kuasa dengan undang-undang sivil sedia ada diperingkat persekutuan. Disamping itu, kedua-dua perundangan yang digunakan di negara kita adalah bersifat selari (parallel). Beberapa statut seperti Akta 97, Akta 98, Mahkamah Tinggi 1980 dan lain-lain telah digubal dalam harta perwarisan harta yang menghadkan bidang kuasa Mahkamah Syariah. ${ }^{32}$ Walaupun setiap negeri mempunyai Enakmen Pentadbiran Agama Islam sendiri seperti yang dijamin Perlembagaan Persekutuan, namun pertindihan kuasa tetap berlaku. Sebagai contoh, dalam seksyen 50(3)(b) Enakmen 4, Pentadbiran Agama Islam Perak (2004) dan yang lainnya menyatakan:

"Dalam bidang kuasa mal nya, mendengar dan memutuskan semua tindakan dan prosiding jika semua pihak dalam tindakan atau prosiding itu ialah orang Islam dan tindakan atau prosiding itu adalah berhubung dengan:

ii) apa-apa pelupusan atau tuntutan harta yang berbangkit daripada mana-mana perkara yang dinyatakan daripada manamana perkara yang dinyatakan dalam subperenggan (i);

iii) nafkah orang-orang tanggungan, kesahtarafan, atau penjagaan atau jagaan (hadhanah) budak-budak;

iv) pembahagian atau tuntutan harta sepencarian;

v) wasiat atau alang yang dibuat semasa marad-al-maut;

vi) alang semasa hidup, atau penyelesaian yang dibuat tanpa balasan yang memadai dengan wang atau nilaian wang oleh seorang orang Islam;

vii) wakaf atau nazr;

31 Suhaimi Ab Rahman, Rasyikah Md Khalid, Adilah Abd Razak \& Abu Bakar Jaafar, 'Pemerkasaan Mahkamah Syariah dalam Pentadbiran Harta Pusaka Masyarakat Islam menurut Kerangka Federalisme di Malaysia,' Akademika, vol. 88/3 (2018): 113-125.

32 Mohamad Naser Disa, 'Penyelarasan Undang-Undang Pewarisan: Isu-Isu Penyelesaiannya,' (Kertas kerja, Konvensyen Perwarisan Harta Islam, Amanah Raya Berhad, 2007), 43-65. 
viii) pembahagian dan perwarisan harta berwasiat atau tak berwasiat;

ix) penentuan orang yang berhak kepada bahagian harta pusaka seseorang si mati yang beragama Islam atau bahagian-bahagian yang kepadanya masing-masing orang itu berhak;

xii) perkara-perkara lain yang berkenaan dengannya bidang kuasa diberikan oleh mana-mana undang-undang bertulis."

Merujuk kepada seksyen 50(3)(b) di atas, Mahkamah Sivil mempunyai peranan dan bidang kuasa yang lebih besar. Peranan Mahkamah Syariah adalah terhad dan tidak mempunyai kuasa dalam perkara probet dan pentadbiran pusaka. Sebaliknya Mahkamah Syariah hanya berperanan untuk mengesahkan sijil faraid bagi harta amanah orang Islam seperti kes melibatkan Azzaharuddin bin Mohd Nadzir lwn Nordin bin Mohd Nazir \& Lain-lain. ${ }^{33}$ Dalam kes ini, Mahkamah Tinggi Syariah telah memutuskan bahawa kuasanya adalah terhad dan tiada kuasa untuk mendengar isu pengisytiharaan sesuatu harta. ${ }^{34}$ Merujuk kepada penulisan Prof Tan Sri Dato Ahmad Ibrahim dalam kertas kerjanya bertajuk "pelaksanaan undang-undang wakaf di malaysia", beliau menjelaskan pelaksanaan undang-undang harta amanah adalah jelas di peringkat negeri. Akan tetapi, apabila pelaksanaannya di lakukan melalui wasiat atau surat amanah ini menyebabkan kes tersebut terpaksa dirujuk kepada Mahkamah Sivil dan mahkamah sesekali tidak terikat dengan fatwa negeri. Sebaliknya keputusan Hakim Mahkamah Sivil adalah bergantung sepenuhnya kepada keputusan Privy Council sebagai autoriti yang mengikatnya.

\section{Pelaksanaan Wiṣāyah dan Amanah di Syarikat Peramanahan}

Berdasarkan kepada konsep wișāyah dalam Islam, MAIN bertindak sebagai pemegang amanah atau wași kepada harta amanah kanak-kanak bawah umur. Ini sebagaimana disebutkan dalam perbincangan lepas serta bidang kuasa enakmen kerajaan di setiap negeri. Namun konsep pelaksanaan wișāyah kini turut diterajui oleh syarikat-syarikat peramanahan yang ditubuhkan di bawah Akta Syarikat 1965 (Akta 125) sama ada secara berdaftar di bawah Akta Syarikat Amanah 1949 (Akta 100) seperti: Amanah Raya Berhad (ARB), Wasiah Shoppee Trustee, as-Salihin Trustee, Labuan Trustee Berhad, CIMB

\footnotetext{
33 Azzaharuddin bin Mohd Nadzir lwn Nordin bin Mohd Nazir \& Lain-lain [2009] 4 ShLR 106

34 Resali Muda, 'Harta Pusaka Islam di Malaysia: Antara Perundangan dan Pentadbiran,' Malaysian Journal of Syariah and Law, vol. 4/1 (2016): 3-5.
} 
Trustee Berhad atau tidak berdaftar di bawah Akta Syarikat Amanah 1949 (Akta 100) seperti rakan strategik korporat bagi syarikat yang dinyatakan. ${ }^{35}$ Hal ini kerana pelaksanaan wiṣāyah kini adalah tertakluk di bawah statut undang-undang sivil.

Bagi memahami konsep pelaksanaan wiṣāyah dengan lebih jelas dan kaitannya secara praktikal dengan amanah sivil, penulis akan memberi penumpuan kepada pelaksanaan amanah di Amanah Raya Berhad (ARB) sebagai salah sebuah syarikat peramanahan di Malaysia. Konsep pelaksanaan amanah di ARB akan dianalisis untuk melihat hubung kaitnya dengan konsep wișāyah.

\section{ARB Sebagai “Public Trustee" di Malaysia}

ARB adalah syarikat penuh milik kerajaan Malaysia yang dahulunya dikenali sebagai Jabatan Pemegang AmanahRaya dan Pegawai Pentadbir Pusaka Malaysia. Mula diasaskan pada tahun 1921 dan merupakan Pemegang Amanah Utama (Public Trustee) di Malaysia yang bertanggung jawab dalam memberikan khidmat peramanahan seperti wasiat, amanah dan pentadbiran harta pusaka ${ }^{36}$. Pada tahun 29 Mei 1995 ARB telah diperbadankan seterusnya didaftarkan dibawah Akta Perbadanan Amanah Raya 1995 (Akta 532) dan Akta Syarikat 1965. Menurut Nik Salina, berdasarkan peruntukan kuasa terkandung di dalam Akta ini, ARB mempunyai kelebihan dalam mengendalikan peramanahan dan pentadbiran harta pusaka (pusaka ringkas) setanding Seksyen Pembahagian Pusaka (pusaka kecil) dan Mahkamah Tinggi (pusaka besar) berdasarkan bidang kuasa yang diperuntukkan. ${ }^{37}$ Inilah perbezaan utama yang dimiliki oleh ARB berbanding syarikat peramanahan berdaftar yang lain kerana mempunyai peruntukan khas melalui akta dalam perlembagaan Malaysia.

Dalam menjalankan tanggungjawabnya sebagai pemegang amanah, bidang kuasa ARB adalah tertakluk kepada seksyen utama di dalam Akta Perbadanan Amanah Raya 1995 (Akta 532):

35 Nasrul Hisyam Nor Muhamad, Wasiat dan Wisayah dalam Perancangan Harta: Prinsip dan Amalan, 155-157.

36 Amanah Raya Berhad, 'Mengenai Amanah Raya Berhad,' https://www. amanahraya.my/ms/tentang-amanah-raya-berhad/ dicapai pada 2 April 2020.

37 Berita Harian, 'Rancang Perwarisan Demi Legasi Masa Depan' https://www. bharian.com.my/rencana/komentar/2017/08/316408/rancang-pewarisan-demilegasi-masa-depan, dicapai pada 2 April 2020. Lihat juga Suhaimi Ab Rahman, Rasyikah Md Khalid \& Abu Bakar Jaafar, 'Kajian Keberkesanan Undang-Undang Faraid di Malaysia,' Akademika, vol. 89 (Isu Khas 2) (2019): 77-91. 
Jadual 1: Bidang Kuasa ARB sebagai Wașī

\begin{tabular}{|c|c|c|}
\hline Akta & Seksyen & Huraian \\
\hline \multirow{5}{*}{$\begin{array}{l}\text { Akta Perbadanan } \\
\text { Amanah Raya } \\
1995 \text { (Akta 532) }\end{array}$} & $\begin{array}{c}\text { Seksyen } 11 \\
\& 12\end{array}$ & $\begin{array}{l}\text { ARB boleh dilantik sebagai pemegang amanah, } \\
\text { wași, pentadbir, penjaga, sahabat wakil, ejen, } \\
\text { wakil, penerima, penerima dan pengurus } \\
\text { atau pelikuidasi atau untuk membuat apa-apa } \\
\text { pelantikan lain yang bersifat fidusiari. }\end{array}$ \\
\hline & Seksyen 13 & $\begin{array}{l}\text { ARB berhak memohon probet dan surat kuasa } \\
\text { mentadbir }\end{array}$ \\
\hline & Seksyen 14 & $\begin{array}{l}\text { Pelantikan ARB sebagai wași, pentadbir atau } \\
\text { pemegang amanah bagi pemegang amanah sedia } \\
\text { ada. Pindah milik harta amanah boleh dilakukan } \\
\text { oleh wași setelah menerima surat kuasa } \\
\text { mentadbir atau geran probet. ARB bertanggung } \\
\text { jawab untuk menjaga harta amanah setelah } \\
\text { menerima perintah mahkamah }\end{array}$ \\
\hline & Seksyen 15 & $\begin{array}{l}\text { Bidang kuasa ARB untuk memohon } \\
\text { mendapatkan surat kuasa mentadbir sekiranya } \\
\text { pemohon asal gagal menjalankan fungsi sebagai } \\
\text { pentadbir. }\end{array}$ \\
\hline & Seksyen 16 & $\begin{array}{l}\text { ARB boleh mengambil harta dan menjadi } \\
\text { pentadbir bagi harta tidak berwasiat sehinga } \\
\text { surat kuasa mentadbir diperoleh. }\end{array}$ \\
\hline
\end{tabular}

Sumber: Akta Perbadanan Amanah Raya 1995 (Akta 532)

Bagi menjayakan pelaksanaan harta amanah di ARB, Nidzamuddin menjelaskan bahawa terdapat dua jenis akaun amanah di ARB yang diwujudkan. Pertama, akaun Amanah Sukarela (Voluntary Trust) iaitu pentadbiran berdasarkan peruntukan terma dan syarat Suratikatan Amanah (SIA) di antara wași dan penderma. Terdapat pelbagai bentuk produk amanah yang ditawarkan di ARB antaranya adalah Normal Trust, Amanah Sukarela, Hibah Amanah, Amanah Hartanah, Amanah Kebajikan, Amanah Institusi, Insurans Amanah, Takaful Amanah dan Edu Care. Setiap akaun amanah yang dibentuk adalah berdasarkan jumlah harta amanah, objektif utama penubuhan dan tempoh peramanahan tertentu yang ditetapkan oleh penderma itu sendiri. Sehingga kini, terdapat pelbagai jenis akaun amanah yang telah diwujudkan di ARB antaranya dalam bentuk Tabung Kebajikan yang kini jumlahnya 
mencecah 100 jenis tabung kebajikan contohnya seperti tabung Wira Negara, Tabung Kebajikan Alexbert, Tabung wakaf Kesihatan (TWKK), Tabung Wira Lahad Datu dan lain-lain lagi. ${ }^{38}$

Konsep pelaksanaan Amanah Sukarela yang dijalankan di ARB disyaratkan berlakunya pindah milik harta amanah daripada pemilikan penderma kepada wași . Penyerahan harta amanah tersebut akan diserahkan kepada benefisiari mengikut surat ikatan amanah yang dimeterai. Penderma boleh menentukan pindah milik harta amanah berlaku selepas kematian dirinya. Melalui akaun Amanah Sukarela juga, penderma boleh menetapkan pelbagai cara pengurusan nafkah kepada benefisiari sama ada secara berkala (automatik) atau permohonan secara manual untuk manfaat benefisiari. Rosmah Mansor menyatakan bahawa, penderma berkuasa mutlak terhadap harta amanah yang telah diserahkan kepada wașī seperti; pembatalan akad amanah, urusan pindah milik dan eksploitasi penggunaan harta amanah. ${ }^{39}$

Proses pelaksanaan Amanah Sukarela ini dapat difahami melalui gambar rajah di bawah:

Rajah 1: Proses Pelaksanaan Amanah Sukarela

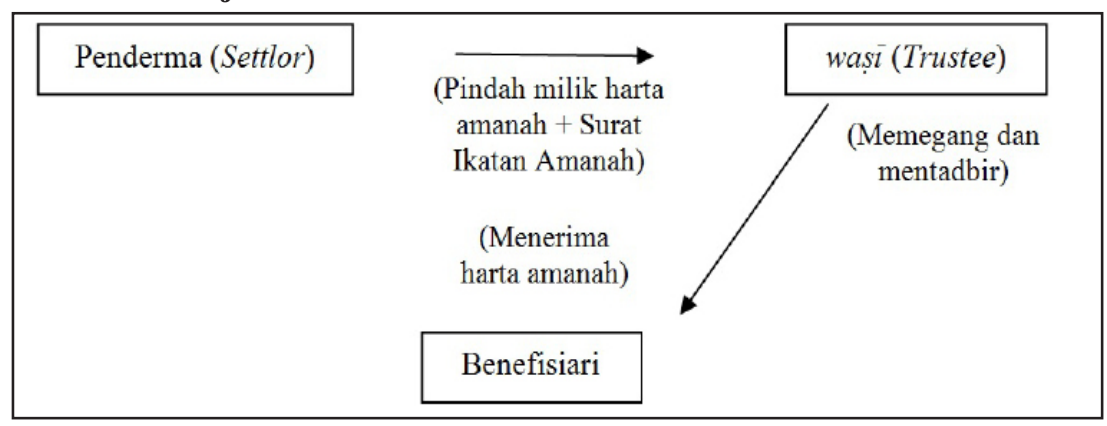

Sumber: Nasrul Hisyam Nor Muhamad ${ }^{40}$

38 Muhammad Nidzamuddin Ibrahim (Eksekutif, Jabatan Pentadbiran Amanah, Amanah Raya Berhad), dalam temu bual beliau bersama penulis pada 5 Mac 2020.

39 Rosmah Mansor (Pengurus Jabatan Pentadbiran Amanah, Amanah Raya Berhad), dalam temu bual beliau bersama penulis pada 5 Mac 2020.

40 Nasrul Hisyam Nor Muhamad, Wasiat dan Wisayah dalam Perancangan Harta: Prinsip dan Amalan, 160. 
Berdasarkan gambar rajah di atas, pelaksanaan amanah adalah sah walaupun tidak berlakunya pemindahan harta amanah secara terus kepada benefisiari. Ini kerana konsep amanah diaplikasikan yang mana waṣī bertindak selaku wakil bagi pihak benefisiari. Malah tidak disyaratkan penerimaan (qabad) daripada pihak benefisiari. Disamping itu, benefisiari juga tidak disyaratkan untuk mengetahui isi kandungan surat ikatan amanah yang telah dimeterai. Menurut Rosmah Mansor lagi, harta amanah tidak akan menjadi pusaka sekiranya penderma meninggal terlebih dahulu daripada benefisiari kerana pelaksanaannya merujuk kepada undang-undang sivil.

Kategori kedua adalah Amanah Mandatori (Involuntary Trust) iaitu pentadbiran harta amanah ditadbir sehingga satu tempoh matang menurut dokumen peramanahan atau perintah yang dikeluarkan oleh pihak ketiga seperti perintah pejabat pesaka kecil, perintah mahkamah tinggi, pampasan tanah, pencen, perintah pejabat buruh, atau pusaka. Amanah mandatori adalah pelengkap kepada Amanah Sukarela. Konsep pelaksanaannya ini akan dijelaskan pada perbahasan seterusnya. ${ }^{41}$

\section{Penjagaan Benefisiari Bawah Umur}

Konsep wișāyah yang dipraktikkan di ARB dapat dilihat dengan lebih jelas lagi melalui peranan wași melalui akaun Amanah Mandatori. Harta amanah yang diterima daripada pihak ketiga akan ditadbir dengan sebaiknya berdasarkan perintah yang dikeluarkan walaupun kecil nilainya. Pelaksanaan ini adalah selaras dengan bidang kuasa yang diperuntukkan berdasarkan kepada Seksyen 11(3) dan Seksyen 14(1), Akta 532, Akta Perbadanan Amanah Raya 1995:

"Seksyen 11(3): Perbadanan tidak boleh enggan menerima apaapa pelantikan semata-mata atas alasan kecilnya nilai harta yang dengannya pelantikan itu berhubungan."

"Seksyen 14(1): Mahkamah boleh, atas permohonan manamana orang yang mempunyai kepentingan benefisial, melantik Perbadanan, jika alasan yang mencukupi ditunjukkan, sebagai ganti kesemua atau mana-mana wasi, pentadbir atau pemegang amanah yang sedia ada."

Bagi benefisiari daripada kalangan kanak-kanak di bawah umur termasuk OKU fizikal, harta amanah tersebut akan ditadbir sehingga mencapai usia

41 Muhammad Nidzamuddin Ibrahim (Eksekutif, Jabatan Pentadbiran Amanah, Amanah Raya Berhad), dalam temu bual beliau bersama penulis pada 5 Mac 2020. 
18 tahun atau 21 tahun. Manakala bagi OKU mental, harta amanah akan ditadbir sehingga meninggal dunia. ${ }^{42}$ Namun begitu, penjaga dibenarkan untuk melakukan sebarang pengeluaran atau permohonan nafkah untuk manfaat benefisiari. Akan tetapi kelulusan permohonan bergantung kepada baki akaun semasa dan justifikasi yang dipertimbangkan oleh wași. Manakala bagi benefisiari bawah umur yang dilantik sebagai penama, sebarang pengeluaran oleh penjaga tidak dibenarkan sehinggalah benefisiari cukup umur. ${ }^{43}$ Ini adalah bertepatan dengan keputusan Jawatankuasa Fatwa Majlis Kebangsaan Bagi Hal EhwalAgama Islam pada 20 September 1973 dan telah dipersetujui oleh Majlis Raja-raja bahawa:

"Penama-penama Kumpulan Wang Simpanan Pekerja, Wang Simpanan Pejabat Pos, Bank, Insuran dan Syarikat Kerjasama sebagai orang-orang yang malaksanakan wasiat si mati atau wasi. Mereka boleh menerima wang si mati dari sumber-sumber tersebut untuk dibahagikan kepada orang-orang yang berhak menurut pembahagian faraid."

Sekiranya benefisiari telah mencapai umur matang, pembayaran akhir akan dilakukan. Akan tetapi sekiranya benefisiari tersebut tidak dapat dikesan keberadaannya atau tiada sebarang tuntutan dibuat kepada wași, maka siasatan terperinci akan dilakukan melalui semakan Agency Link-Up System (ALIS) di bawah seliaan Jabatan Pendaftaran Negara (JPN). Jejak waris (care visit) juga akan dijalankan sekiranya timbul keraguan terhadap wang amanah yang ditadbir oleh penjaga. Bagi benefisiari yang tidak dapat dikesan setelah siasatan menyeluruh dilakukan maka wang amanah tersebut akan dipindahkan ke Jabatan Pengurusan Dana Tertangguh (JPDT), salah satu jabatan di ARB yang ditubuhkan khas pada tahun 2017 untuk menguruskan harta amanah tidak dituntut. Wang amanah tersebut akan disimpan sehinggalah terdapat tuntuntan oleh benefisiari atau waris-waris yang berhak. Sekiranya benefisiari telah meninggal dunia, proses pentadbiran pusaka perlu dilakukan dengan

42 Kebiasaannya sesuatu perintah mahkamah (court order) yang diterima oleh wași dari Mahkamah Sivil yang melibatkan benefisiari OKU mental, tidak dinyatakan tempoh peramanahannya adalah seumur hidup. Oleh kerana itu, untuk kemaslahatan benefisiari OKU mental tersebut, maka wași mengambil inisiatif menjaga harta amanah tersebut sehingga benefisiari OKU mental meninggal dunia. Penjaga yang telah dilantik oleh mahkamah akan dimaklumkan perkara ini dan dinasihatkan mengekalkan harta amanah tersebut di ARB.

43 Noorhajar Abu Bakar (Eksekutif Kanan, Jabatan Pentadbiran Amanah Amanah Raya Berhad), dalam temu bual beliau bersama penulis pada 5 Mac 2020. 
segera dan harta amanah tersebut akan diserahkan kepada waris-waris yang berhak setelah wașī menerima Surat Kuasa Mentadbir (SKM).

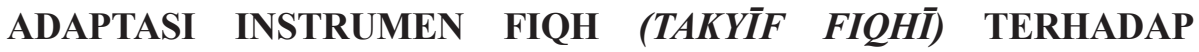 AMANAH SIVIL}

Setelah melihat kepada konsep pelaksanaan amanah di ARB melibatkan kedua-dua jenis akaun amanah yang dinyatakan di atas berserta statut undangudang sivil diperuntukkan, penulis melihat instrumen fiqh (takyīf fiqhī) amanah sivil ini adalah menyamai konsep wișāyah dalam Islam. Walaupun terdapat beberapa perbezaan dengan konsep wiṣāyah yang diamalkan di Majlis Agama Islam Negeri (MAIN), namun penulis melihat konsep pelaksanaan dan maqasidnya adalah sama, iaitu menjaga harta amanah dan kepentingan benefisiari. Perbezaan yang timbul tidak menjadi penghalang untuk wașī menunaikan tanggung jawab yang diamanahkan.

Akan tetapi, beberapa penelitian perlu diberikan untuk memastikan produk yang dibuat bertepatan dengan kehendak Syariah. Ini kerana, terdapat beberapa isu dari perspektif Syariah melibatkan akad peramanahan yang memerlukan kepada penilaian khususnya melibatkan akaun Amanah Sukarela. Ini kerana syarat-syarat peramanahan bebas ditetapkan oleh muși dan ini berbeza sama sekali dengan Amanah Mandatori. Bahkan Akmal Hidayah memberi penegasan bahawa konsep amanah sivil yang dipraktikkan kini perlu dinilai semula pelaksanaannya berdasarkan tiga faktor utama: pembatalan akad amanah, pindah milik dan manipulasi terhadap servis amanah. ${ }^{44}$

\section{Isu Pembatalan Akad Amanah}

Berdasarkan pelaksanaan Amanah Sukarela, penderma bebas untuk meletakkan sebarang syarat di dalam surat ikatan amanah bagi harta yang diamanahkan. Ini termasuklah pembatalan amanah tersebut boleh berlaku pada bila-bila masa mengikut keinginan penderma. Malah penderma juga berhak untuk menentukan takat umur yang difikirkan layak dan kriteriakriteria tertentu terhadap benefisiari untuk diserah milik. Konsep amanah ini adalah tidak bertepatan dengan konsep pemberian hibah yang sebenar. Di dalam Islam, perletakan syarat bagi sesuatu pemberian harta dibenarkan seperti yang diamalkan dalam konsep hibah bersyarat seperti 'umra dan

44 Akmal Hidayah Halim, 'The Legality of A Living Trust As An Instrument for Islamic Wealth Management: A Malaysian Perspective,' 35-50. 
ruqba. ${ }^{45}$ Akan tetapi, bagi pemberian mutlak (inter vivos), tidak dibenarkan berlaku pembatalan kecuali daripada seorang ayah kepada seorang anak atau daripada seorang datuk kepada seorang cucu. ${ }^{46}$

\section{Pindah Milik (Ownership Transfer)}

Berdasarkan pengamalan amanah sivil sekarang, harta amanah yang dipegang oleh wași masih menjadi hak milik penderma kerana ianya adalah suatu akad yang tersendiri. Pelaksanaan ini berbeza sama sekali dengan konsep hibah atas dasar kasih sayang kepada benefisiari kerana pindah milik dalam amalan hibah adalah jelas berlaku. ${ }^{47}$ Berbanding amanah sivil, penderma bebas untuk menikmati dan menggunakan harta amanah yang diperuntukkan kepada benefisiari tanpa pengetahuan benefisiari bahkan penderma bebas untuk mengubah syarat peramanahan secara mutlak. Ini kerana, pemilikan sempurna (al-milk al-tam) tidak berlaku di pihak benefisiari. Secara tidak langsung memberi implikasi buruk kepada konsep amanah yang dilakukan sekiranya berlaku salah faham dalam kalangan waris apabila berlaku kematian penderma.

\section{Manipulasi Terhadap Servis Amanah}

Akaun amanah sivil yang diwujudkan oleh penderma adalah tidak termasuk dalam kategori harta pusaka yang perlu difaraidkan kepada ahli waris yang berhak. Pelaksanaannya adalah bebas dan tidak mengikut kadar hukum wasiat, iaitu hanya terhad 1/3 sahaja kepada bukan kepada ahli waris. Malah akaun amanah sivil tidak boleh dicabar kesahihannya di mahkamah. ${ }^{48}$ Oleh kerana itu, pelaksanaan amanah sivil ini dibimbangi menjadi satu hilah tidak syari' (al-hiyal ghayr shar 'iyyah) oleh penderma untuk mengelakkan harta

45 Nasrul Hisyam Nor Muhamad, 'Pemakaian Prinsip Hibah dalam Sistem Kewangan Islam di Malaysia: Tumpuan Kepada Industri Perbankan Islam dan Takaful,' Jurnal Teknologi (2010): 69-81.

46 Al-Nawawī, Yạ̣yā bin Sharf, Minhāj al-Ṭālibìn wa 'Umdah al-Muftīn fì al-Fiqh (Bayrūt, Lubnān: Dār al-Fikr, 2005), 172.

47 Akmal Hidayah Halim, 'The Legality of A Living Trust As An Instrument for Islamic Wealth Management: A Malaysian Perspective,' 35-50. Lihat juga Akmal Hidayah Halim \& Tajul Aris Ahmad Bustami, 'Pelaksanaan Hibah Amanah sebagai Suatu Instrumen Pengurusan Harta Islam di Malaysia,' 93-95.

48 Rosmah Mansor (Pengurus Jabatan Pentadbiran Amanah, Amanah Raya Berhad), dalam temu bual beliau bersama penulis pada 5 Mac 2020 . 
pusakanya daripada diwarisi mengikut Hukum Syarak walaupun niat asalnya adalah baik. ${ }^{49}$

Syamsuri menyatakan bahawa terdapat dikalangan penderma yang melaksanakan amanah yang bertindak sedemikian terutamanya melibatkan pindah milik hartanah. Menurut beliau, sekiranya penderma benar-benar berhajat menyerahkan hartanah kepada benefisiari, sudah pasti akan melakukan pindah milik secara mutlak. Akan tetapi, disebabkan faktor tertentu, penderma memilih pelaksanaan amanah hartanah (property trust) yang berteraskan amanah sivil. ${ }^{50}$ Walaupun pelaksanaannya memenuhi kehendak penderma, akan tetapi penilaian semula perlu dilakukan bagi memastikan objektif pelaksanaannya tidak dimanipulasikan.

\section{GARIS PANDUAN PELAKSANAAN AMANAH SIVIL}

Wișāyah dan amanah adalah instrumen pengurusan harta yang fleksibel dan sesuai diaplikasikan dalam semua instrumen perancangan harta pusaka terutama sekiranya penderma memilik anak-anak bawah umur atau OKU. Berdasarkan perbincangan lalu mengenai adaptasi instrumen fiqh (takyīffiqhī), Penulis berpandangan perlunya satu garis panduan untuk mengharmonikan konsep amanah sivil kontemporari dengan konsep wiṣāyah dalam Islam.

Pertama, bagi mengelakkan timbulnya sebarang eksploitasi terhadap harta amanah oleh penderma, penggunaan hibah dicadangkan sebagai ganti kepada akad permanahan sedia ada. Hibah adalah satu bentuk pemberian kasih sayang tanpa mengharapkan balasan dan tidak berlaku sebarang manipulasi terhadap harta amanah tersebut. ${ }^{51}$ Penarikan atau pembatalan hibah juga tidak dibenarkan kecuali daripada seorang ayah kepada anaknya. Hibah juga terbukti sebagai instrumen perancangan harta untuk menyelesaikan sebarang konflik sewaktu hidup dan juga masalah pengurusan harta pusaka selepas kematian. ${ }^{52}$

49 Ibn 'Āshūr, Muhamad al-Ṭāhir bin Muḥammad, Maqāṣid al-Shārī'ah alIslāmiyyah, vol. 2 (Qațar: Wizārah al-Awqāf wa al-Shu'ūn Islāmiyyah, 2004), 323.

50 Syamsuri Idris (Eksekutif, Jabatan Pentadbiran Amanah, Amanah Raya Berhad), dalam temu bual beliau bersama penulis pada 5 Mac 2020.

51 Muștafā al-Khin, Muștafā al-Bughā, 'Alī al-Sharbajī, al-Fiqh al-Manhaj̄̄ 'alā Madhhab al-Imām al-Shāfi 'ī, vol. 6, 115-116.

52 Alias Azhar, Mohammad Azam Hussain, Muhammad Hafiz Badarulzaman \& Fauziah Mohd Noor, 'Pengurusan Harta dalam Islam: Perspektif Hibah di Malaysia,' Journal of Human Development and Communication (2014): 115-128. 
Kedua, penderma juga boleh memilih untuk melaksanakan hibah amanah iaitu gabungan di antara akad hibah dan amanah sivil. Melalui pelaksanaan ini, pindah milik harta amanah akan diserahkan kepada wași sewaktu hidup untuk ditadbir terlebih dahulu. ${ }^{53}$ Konsep umra dan ruqba juga boleh diguna pakai oleh penderma untuk meletakkan syarat pindah milik hanya berlaku selepas kematiannya. Melalui pelaksanaan hibah bersyarat dan hibah amanah ini, ianya menjadi bukti bahawa penderma benar-benar inginkan harta amanah tersebut diberikan kepada benefisiari yang dikehendaki. Akan tetapi, disebabkan ingin mengekalkan kawalan ke atas harta amanah tersebut atas faktor-faktor tertentu, kedua-dua konsep hibah ini boleh diaplikasikan. Selain itu, pelaksanaannya dapat menjamin kesahan akad yang dilakukan kerana berlaku qabad pemilihan harta di pihak benefisiari melalui surat ikatan amanah yang dimeterai setiap pihak.

Ketiga, walaupun penderma berhak untuk meletakkan sebarang syarat dalam surat ikatan amanah, akan tetapi menjadi kewajipan waṣī untuk menjelaskan batasan Hukum Syarak untuk memastikan pelaksanaannya patuh Syariah. Penderma perlu diingatkan bahawa harta amanah yang dilakukan kepada benefisiari tidak boleh dikeluarkan atau dimanfaatkan tanpa sebab-sebab yang munasabah sehingga benefisiari mencapai umur matang. Sekiranya harta amanah tersebut dimanfaatkan sesuka hati, hak dan kepentingan benefisiari akan terkesan sekiranya penderma meninggal dunia pada ketika itu. Garis panduan ini diharapkan dapat mengharmonikan konsep amanah sivil yang dipraktikkan sekarang agar perlaksanaannya memenuhi tuntutan Syariah.

\section{PERBEZAAN DI ANTARA WIȘĀYAH DAN AMANAH}

Berdasarkan hasil perbincangan berkenaan konsep pelaksanaan wișāyah dan amanah sivil di atas, berikut dinyatakan perbezaan di antara keduanya dalam jadual berikut:

\section{Jadual 2: Perbezaan di antara Wị̦āyah dan Amanah}

\begin{tabular}{ccl}
\hline No. & \multicolumn{1}{c}{ Wișāyah } & \multicolumn{1}{c}{ Amanah Sivil } \\
\hline 1. & $\begin{array}{l}\text { Tertakluk di bawah undang-undang } \\
\text { Islam berdasarkan al-Quran dan as- } \\
\text { Sunnah. }\end{array}$ & $\begin{array}{l}\text { Berasal dari konsep ekuiti undang- } \\
\text { undang Inggeris. }\end{array}$
\end{tabular}

53 Mohd Yazid Zulkepli \& Tajul Aris Ahmad Bustami, 'The Grey Side of Hibah Amanah As Inheritance Instrument in Malaysia,' Al-Shajarah, vol. 24/2 (2019): 267-292. 
2. Tertakluk di bawah Perlembagaan Persekutuan: Jadual Kesembilan, Senarai II, Senarai Negeri merangkumi wakaf, harta pusaka berwasiat dan tidak berwasiat, harta sepencarian, hadhanah, hibah.
Tertakluk di bawah perlembagaan persekutuan Jadual Kesembilan, Senarai 1, S.4(E)(i). Juga Melibatkan Akta Pemegang Amanah 1949 (Akta 208), Akta Syarikat Amanah 1949 (Akta 100), Akta Pemegang Amanah (Perbadanan) 1952, Akta Pembahagian 1958, Akta Wasiat 1959, Akta Insuran 1996 dan lain-lain.

Pelantikan wașī sewaktu hidup dan pelaksanaannya boleh berlaku sewaktu hayat penderma atau selepas kematian penderma.

4. Rukun wisāyah melibatkan pewasiat (mușī), pemegang amanah (wași ), objek peramanahan (mușa 'alayh), lafaz ijab dan qabul (sìghah)

5. Sekiranya penderma meninggal dunia terlebih dahulu, harta amanah termasuk dalam harta pusaka.

6. Harta amanah tidak boleh dieksploitasi oleh penderma.

7. Syarat wași adalah: Islam , baligh, berakal, adil, lelaki, tiada permusuhan dengan muṣī. Konsep wași juga dipertanggung jawabkan kepada MAIN.

8. Muși dan benefisiari adalah orang berlainan.
Rukun amanah melibatkan settlor, benefisiari, harta amanah. Akan tetapi tidak perlu berlaku qabad harta amanah di pihak benefisiari.

Tidak termasuk dalam harta pusaka selepas akad permanahan di laksanakan setelah kematian penderma. Harta amanah adalah milik benefisiari seperti dinamakan dalam surat ikatan amanah.

Harta amanah boleh dieksploitasi oleh penderma sewaktu hidup.

Tidak disyaratkan wașī adalah Islam , baligh, berakal, adil, lelaki. wașī boleh dilantik daripada sesebuah syarikat peramanahan yang berdaftar dengan Akta Syarikat Amanah 1949 (Akta 100).

Settlor boleh menjadi benefisiari seumur hidup, atau sebagai pemegang amanah. 


\begin{tabular}{cll}
\hline No. & \multicolumn{1}{c}{ Wișāyah } & \multicolumn{1}{c}{ Amanah Sivil } \\
\hline 9. & $\begin{array}{l}\text { Harta hanya dipindah milik kepada } \\
\text { wași selepas kematian. }\end{array}$ & $\begin{array}{l}\text { Harta amanah dipindah milik kepada } \\
\text { wași berdasarkan surat ikatan amanah } \\
\text { sewaktu hidup }\end{array}$ \\
10. & Wișāyah untuk orang Islam. & $\begin{array}{l}\text { Amanah melibatkan orang Islam dan } \\
\text { bukan Islam }\end{array}$ \\
11. & $\begin{array}{l}\text { Proses perundangan di Mahkamah } \\
\text { Syariah }\end{array}$ & $\begin{array}{l}\text { Proses perundangan di Mahkamah } \\
\text { Sivil }\end{array}$ \\
\hline
\end{tabular}

Sumber: Analisis penulis

\section{PENUTUP}

Berdasarkan perbincangan di atas, penulis mendapati bahawa instrumen perancangan harta pusaka melalui wișāyah dan amanah sivil memainkan peranan yang penting dalam melindungi hak dan kepentingan benefisiari. Adalah penting bagi seorang penjaga untuk melantik seorang wașī yang benarbenar bertanggung jawab bagi menguruskan nafkah, kos rawatan kesihatan, hutang piutang dan sebagainya untuk mengelakkan penjagaan benefisiari terabai selepas kematiannya. Walaupun wișāyah dan amanah sivil merujuk kepada dua perundangan yang berbeza, penulis melihat bahawa perundangan sivil sedia ada seperti yang terdapat pada bidang kuasa ARB melalui Akta Perbadanan Amanah Raya 1995 (Akta 532) dan Akta Syarikat Amanah 1949 (Akta 100) adalah pelengkap kepada enakmen-enakmen wișāyah yang dilaksanakan oleh MAIN di seluruh Malaysia. Ini kerana, peruntukan amanah sivil mempunyai bidang kuasa yang lebih meluas.

Di samping itu, hasil pengamatan penulis mendapati bahawa kedua-dua instrumen perancangan harta pusaka ini mempunyai tujuan dan maksud yang sama dalam melindungi kepentingan benefisiari. Tidak dinafikan bahawa terdapat pertikaian dan isu penghakiman yang dilihat tidak menyebelahi undang-undang Islam seperti kes penghakiman TM Feroze Khan \& Ors lwn Meera Hussain TM Mohamed Mydin. Begitu juga dalam isu akad peramanahan sivil yang dilihat tidak selari dengan konsep akad di dalam Islam. Justeru, beberapa garis panduan pelaksanaan sivil amanah ini perlu dipertimbangkan pelaksanaannya untuk memastikan akad peramanahan yang dijalankan mengikut ketetapan Syarak. 


\section{RUJUKAN}

'Abd Allāh Muḥammad Sa‘̄̄d, 'al-Wișāyah fī al-Fiqh al-Islāmī wa Qānūn al-Aḥwāl al-Shakhșiyyah al-Urdūn̄i: Dirāsah Muqāranah’ (Risālah alDuktūrah, fī al-Fiqh wa Ușūl al-Fiqh, Kulliyyah al-Dirāsāh al-'Ulyā, al-Jāmi'ah al-Urdūniyah, 2005).

Abī Dāwud, Sulayman bin al-Ash'ath, Sunan Abī Dāwud, vol. 3 (Bayrūt, Lubnān: al-Maktabah al-'Așriyyah, t.t.).

Abdullah Muhammad, 'Pengamanahan Harta Orang Islam di Malaysia,' dalam Harta Amanah Orang Islam di Malaysia: Perspektif Undang-Undang dan Pentadbiran, ed. Siti Mashitoh Mahamood (Kuala Lumpur: Penerbit Universiti Malaya, 2006), 123-132.

Akmal Hidayah Halim, 'The Legality of A Living Trust As An Instrument for Islamic Wealth Management: A Malaysian Perspective,' IIUM Law Journal, vol. 19/1 (2011): 35-50.

Akmal Hidayah Halim \& Tajul Aris Ahmad Bustami, 'Pelaksanaan Hibah Amanah sebagai Suatu Instrumen Pengurusan Harta Islam di Malaysia,' Kanun: Jurnal Undang-Undang Malaysia, vol. 29/2 (2017): 90-115.

Al-Bukhārī, Muhammad bin Ismā'īl, Șaḥịh al-Bukhārī, vol. 8 (Bayrūt, Lubnān: Dār Țūq al-Najāh, 2001).

Al Azifah Mohd Safie, 'Penderafan Dokumen Wasiat Islam di Amanah Raya Berhad: Analisis Menurut Perspektif Islam,' (Disertasi Sarjana, Jabatan Syariah dan Undang-Undang, Akademi Pengajian Islam, Universiti Malaya, 2010).

Alias Azhar, Mohammad Azam Hussain, Muhammad Hafiz Badarulzaman \& Fauziah Mohd Noor, 'Pengurusan Harta dalam Islam: Perspektif Hibah di Malaysia,' Journal of Human Development and Communication (2014): 115-128.

Amanah Raya Berhad, 'Mengenai Amanah Raya Berhad,' https:/www. amanahraya.my/ms/tentang-amanah-raya-berhad/ dicapai pada 2 April 2020.

Andi Mohamad Zulkhairi Muhamad, 'Konsep Amanah dalam Pengurusan Islam dari Sudut Maqasid Syariah (Penjagaan Harta),' Prosiding Seminar Pengurusan Islam: Ke Arah Pemantapan Ummah (Bangi: Jabatan Pengajian Dakwah dan Kepimpinan, Fakulti Pengajian Islam, Universiti Kebangsaan Malaysia, 2015), 1-9.

Al-Nawawī, Yahỵā bin Sharf, Minhāj al-Ṭālibīn wa 'Umdah al-Muftīn fì alFiqh (Bayrūt, Lubnān: Dār al-Fikr, 2005). 
Ashrāf Hanḍal al-Shā'īr, 'Aḥkām al-Wișāyah fī al-Sharī'ah al-Islāmiyah wa Madā Taṭbīqatuhā fī al-Maḥākim al-Shar'iyyah fī Qiṭa' al-Ghazzah’ (Risālah al-Mājistir, Kulliyyah al-Shārīah wa al-Qānūn, al-Jāmi‘ah alIslāmiyyah bi Ghazzah, 2006).

Badruddin Hj Ibrahim, 'The Concept of al-Wisayah with Special Reference to the Administration of A Minor's Property Under Islamic Law and the Enacted Islamic Law in Malaysia,' (Ph.D Thesis, Kulliyyah UndangUndang Ahmad Ibrahim, Universiti Islam Antarabangsa Malaysia, 2006).

Badruddin $\mathrm{Hj}$ Ibrahim, 'Will of Entrustment As A Means of Protection of Children's Right To Property in Islamic Law,' Australian Journal of Basic and Applied Sciences, vol. 6/11 (2012): 85-94.

Berita Harian, 'Rancang Perwarisan Demi Legasi Masa Depan' https:// www.bharian.com.my/rencana/komentar/2017/08/316408/rancangpewarisan-demi-legasi-masa-depan, dicapai pada 2 April 2020.

Ibn 'Āshūr, Muhamad al-Ṭāhir bin Muhammad, Maqāṣid al-Shārī'ah alIslāmiyyah, vol. 2 (Qațar: Wizārah al-Awqāf wa al-Shu'ūn Islāmiyyah, 2004).

Izawati Wook, Nawal Sholehuddin, Nurfadhilah Che Amani, Siti Selihah Che Hassan, Azman Ab. Rahman, Mohamad Zaharuddin Zakaria \& Tengku Mansur Tengku Zainal Abidin, 'Tanah Adat di Negeri Sembilan: UndangUndang, Pelaksanaan dan Realiti,' Malaysian Journal of Syariah and Law, vol. 5 (Khas) (2017): 1-10.

Kasimah Kamaruddin \& Md. Yazid Ahmad, 'Analysis of the Understanding of Muslim Will Writing in Melacca,' Islāmiyyāt, vol. 34 (2012): 71-82

Mohd Yazid Zulkepli \& Tajul Aris Ahmad Bustami, 'The Grey Side of Hibah Amanah As Inheritance Instrument in Malaysia,' Al-Shajarah, vol. 24/2 (2019): 267-292.

Mohamad Naser Disa, 'Penyelarasan Undang-Undang Pewarisan: Isu-Isu Penyelesaiannya,' (Kertas kerja, Konvensyen Perwarisan Harta Islam, Amanah Raya Berhad, 2007), 43-65.

Muḥamad Sa'īd Ṭanțāwī, al-Tafsīr al-Wasìt li al-Qur'ān al-'Ażìm, vol. 5 (Qāhirah: Dār al-Naḥ̣̣ah, 1997).

Mușțafā al-Khin, Muștafā al-Bughā, 'Alī al-Sharbaj̄̄, al-Fiqh al-Manhaj̄̄ 'alā Madhhab al-Imām al-Shāfi ‘̄, vol. 5 \& 6 (Dimashq: Dār al-Qalam, 1992).

Nasrul Hisyam Nor Muhamad, 'Pemakaian Prinsip Hibah dalam Sistem Kewangan Islam di Malaysia: Tumpuan Kepada Industri Perbankan Islam dan Takaful,' Jurnal Teknologi (2010): 69-81. 
Nasrul Hisyam Nor Muhamad, Wasiat dan Wisayah dalam Perancangan Harta: Prinsip dan Amalan (Skudai: UTM Press, 2012).

Naziree Md Yusof, 'Hukum Wisoyah \& Realiti Permasalahannya dalam Konteks Perancangan Pusaka Islam,' Jurnal Muamalat, vol. 1 (2008): 73-102.

Norazlina Abdul Aziz, Irini Ibrahim \& Mohd Norhusairi Mat Hussin, 'Harta Sepencarian/Aset Perkahwinan Bagi Pembubaran Perkahwinan di Bawah Seksyen 51 Akta Membaharui Undang-undang (Perkahwinan dan Perceraian) 1976 Serta Akta Undang-Undang Keluarga Islam (WilayahWilayah Persekutuan) 1984,' Journal of Shariah Law Research, vol. 4/1 (2019), 1-26.

Othman Yaacob, 'Pembentukan Trust Hibah sebagai Alternatif Perancangan Harta,' dalam Harta Amanah Orang Islam di Malaysia: Perspektif Undang-Undang dan Pentadbiran, ed. Siti Mashitoh Mahamood (Kuala Lumpur: Penerbit Universiti Malaya, 2006), 171-207.

Resali Muda, 'Harta Pusaka Islam di Malaysia: Antara Perundangan dan Pentadbiran,' Malaysian Journal of Syariah and Law, vol. 4/1 (2016): 3-5.

Sayyid Sābiq, Fiqh al-Sunnah, vol. 3 (Bayrūt, Lubnān: Dār al-Kutub al-'Arabī, 1997).

Suhaili Alma'amun, 'Islamic Estate Planning: Analysing the Malaysian Perceptions on Wasiyyah (Will) and Bequest Practices,' (Ph.D Thesis, Institute of Middle Eastern and Islamic Studies, School of Government and International Affair, Durham University 2010).

Suhaimi Ab Rahman, Rasyikah Md Khalid, Adilah Abd Razak \& Abu Bakar Jaafar, 'Pemerkasaan Mahkamah Syariah dalam Pentadbiran Harta Pusaka Masyarakat Islam menurut Kerangka Federalisme di Malaysia,' Akademika, vol. 88/3 (2018): 113-125.

Suhaimi Ab Rahman, Rasyikah Md Khalid \& Abu Bakar Jaafar, 'Kajian Keberkesanan Undang-Undang Faraid di Malaysia,' Akademika, vol. 89 (Isu Khas 2) (2019): 77-91.

Tun Abdul Hamid Omar, 'Bidang Kuasa Mahkamah Sivil dalam Pentadbiran Harta Amanah di Malaysia,' https://tunabdulhamid.me/2001/11/ bidangkuasa-mahkamah-sivil-dalam-pentadbiran-harta-amanahdimalaysia/, dicapai pada 13 April 2020. 


\section{Senarai Statut}

Perlembagaan Persekutuan Malaysia

Akta Pemegang Amanah 1949 (Akta 208)

Akta Syarikat Amanah 1949 (Akta 100)

Akta Pemegang Amanah (Perbadanan) 1952

Akta Perbadanan Amanah Raya 1955 (Akta 532)

Akta Syarikat Amanah Labuan (1990 (Akta 442)

Akta Pembahagian 1958 (Akta 300)

Akta Pesaka Kecil (Pembahagian) 1955 (Akta 98)

Akta Probate Dan Pentadbiran 1959 (Akta 97)

Akta Perwarisan (Peruntukan Keluarga) Akta 1971

Akta Wasiat 1959 (Akta 346)

Akta Insuran 1996

Akta Kanun Tanah Negara 1965

Akta Undang-Undang Keluarga Islam (Wilayah Persekutuan) 1984

Enakmen Pentadbiran Agama Islam (Negeri Selangor) 2003

Enakmen Pentadbiran Agama Islam Perak (2004)

\section{Senarai Kes}

Azzaharuddin bin Mohd Nadzir lwn Nordin bin Mohd Nazir \& Lain-lain [2009] 4 ShLR 106

TM Feroze Khan \& Ors lwn Meera Hussain TM Mohamed Mydin [2006] 3 CLJ 616

Wan Naimah lwn Wan Mohamad Nawawi (1974) 1 MLJ 41

Yong Nyee Fan \& Sons Sdn. Bhd v Kim Guan \& Co. Sdn. Bhd [1979] 1 MLJ 182

\section{Temu bual}

Muhammad Nidzamuddin Ibrahim (Eksekutif, Jabatan Pentadbiran Amanah, Amanah Raya Berhad), dalam temu bual beliau bersama penulis pada 5 Mac 2020. 
Noorhajar Abu Bakar (Eksekutif Kanan, Jabatan Pentadbiran Amanah Amanah Raya Berhad), dalam temu bual beliau bersama penulis pada 5 Mac 2020.

Rosmah Mansor (Pengurus Jabatan Pentadbiran Amanah, Amanah Raya Berhad), dalam temu bual beliau bersama penulis pada 5 Mac 2020.

Syamsuri Idris (Eksekutif, Jabatan Pentadbiran Amanah, Amanah Raya Berhad), dalam temu bual beliau bersama penulis pada 5 Mac 2020. 
Jurnal Syariah, Jil. 28, Bil. 2 (2020) 157-188 